\author{
Aleksandra Kalata-Zawtocka (D) \\ Uniwersytet Warszawski \\ a.kalata@uw.edu.pl
}

\title{
Głusi i tłumacze PJM o thumaczeniu języka migowego w Polsce kiedyś i dziś
}

\section{Wprowadzenie}

Niniejszy artykuł poświęcony jest, zgodnie z tematyką całego tomu, przekładowi ustnemu, tyle że w odmiennej od języków fonicznych, kojarzonych zazwyczaj z tłumaczeniem ustnym, modalności. Modalność, o której mowa, jest manualno-przestrzenna, język zaś, który się w niej przejawia, to polski język migowy (PJM) - naturalny, często pierwszy i/lub preferowany system komunikacji około 50 tysięcy Głuchych ${ }^{1}$ Polaków². Uzyskanie przez języki migowe statusu języków naturalnych było możliwe dzięki pionierskim badaniom Williama Stokoe’a, który w 1960 roku przedstawił opis gramatyczny amerykańskiego języka migowego (ASL). Niemal dwie dekady później przekład języków migowych zaczął być uważany za rodzaj przekładu ustnego (ang. sign language

\footnotetext{
1 Pisownia wyrazu ,głuchy” wielką literą odnosi się do Głuchych jako mniejszości językowo-kulturowej. Pisownia tego wyrazu małą literą odnosi się do głuchych jako osób o pewnym ubytku słuchu.

2 <https://www.pzg.org.pl/2020/11/mam-prawo-do-informacji-w-pjm/ >, dostęp 6.01.2021.
} 
interpreting). Jako jedna z pierwszych pisała o tym w 1981 roku Sharon Neumann-Solow: „Interpreting - the process of transmitting spoken English into American Sign Language and/or gestures for communication between deaf and hearing people" [1981: xi], a za nią kolejni autorzy:

Interpretation refers to the process of changing messages produced in one language immediately into another language. The languages in question may be spoken or signed, but the defining characteristic is the live and immediate transmission [Frishberg 1990: 18].

W 1997 roku Andrzej Kopczyński uwzględnił tłumaczenie języka migowego w swojej typologii przekładu obok innych form tłumaczenia ustnego. W ślad za nim Franz Pöchhacker [2004] zaliczył thumaczenie języka migowego oraz tłumaczenie tekstów pisanych na język migowy do tłumaczenia symultanicznego.

Od lat 70. XX wieku trwają badania nad przekładem języków migowych: początkowo poświęcone głównie amerykańskiemu językowi migowemu, następnie językom migowym w krajach europejskich [Kalata-Zawłocka 2017]. Powstało wiele prac naukowych wskazujących na liczne podobieństwa między przekładem języków fonicznych i migowych [Bélanger 1998; Kellet-Bidoli 2001; Kalata-Zawłocka 2003]. Z początkiem XXI wieku tłumaczenie języka migowego stało się również przedmiotem badań w Polsce [Kalata-Zawłocka 2017].

\section{Badanie}

Badanie będące przedmiotem artykułu zostało przeprowadzone wśród przedstawicieli środowisk osób głuchych i tłumaczy PJM. Każda z grup miała możliwość przedstawienia swojego spojrzenia na tłumaczenie PJM, podzielenia się obserwacjami i doświadczeniami w tym zakresie z perspektywy odbiorców tłumaczenia lub osób je zapewniających. Badanie miało na celu zobrazowanie rozwoju tłumaczenia PJM, zmian, jakie zaszły w środowiskach zarówno osób głuchych, jak i tłumaczy, a także bardziej ogólnie - w polskim społeczeństwie.

\subsection{Metodologia i charakterystyka grupy}

Badanie trwało od października 2020 do stycznia 2021 roku. Miało formę częściowo ustrukturyzowanych wywiadów przeprowadzanych po polsku lub w PJM. W badaniu uczestniczyło 12 osób głuchych i 11 tłumaczy. Obie 
grupy badanych odpowiadały na ten sam zestaw 15 pytań. W związku z sytuacją epidemiczną wywiady były przeprowadzane online lub przez telefon, w większości $(\mathrm{n}=21)$ były też nagrywane. Następnie zostały poddane transkrypcji i zakodowane - badanym z grupy osób głuchych zostały przyporządkowane litery $\mathrm{G} z$ numerem od 1 do 12 , zaś osoby badane $\mathrm{z}$ grupy thumaczy zostały opisane literą $\mathrm{T}$ z numerem od 1 do 11 . Czas trwania wywiadów wynosił od jednej do ponad dwóch godzin. Osoby badane były pozyskiwane do udziału w badaniu dzięki kontaktom prywatnym autorki. Kryteria doboru głuchych uczestników badania obejmowały posługiwanie się PJM w codziennych sytuacjach komunikacyjnych i doświadczenie w korzystaniu z usług thumaczenia PJM. Spośród 12 badanych 7 pochodziło z Warszawy, 5 z większych miast w 5 województwach. Badani (5 kobiet, 7 mężczyzn) w wieku od 25 do 52 lat posiadali wykształcenie wyższe lub średnie i reprezentowali różne grupy zawodowe. Wszyscy byli w pewien sposób związani ze środowiskiem Głuchych i językiem migowym: jako lektorzy i thumacze PJM, nauczyciele dzieci głuchych, działacze, naukowcy, przedstawiciele organizacji pozarządowych.

W przypadku tłumaczy PJM istotne było ich doświadczenie oraz aktywność zawodowa. Badanymi były same kobiety w wieku od 31 do 58 lat, mające co najmniej kilka lat doświadczenia w tłumaczeniu PJM, zarówno środowiskowym, jak i konferencyjnym, w środowisku akademickim i artystycznym. 5 uczestniczek badania było CODA (ang. Child of Deaf Adult), czyli miało jednego lub oboje rodziców głuchych, 6 nie pochodziło ze środowiska głuchych. 5 badanych pochodziło z Warszawy, 6 z większych miast z 4 województw.

W pierwszej części wywiadu badani wypowiadali się na temat zmian zaobserwowanych w obszarze tłumaczenia języka migowego w Polsce, z których większość dokonała się w ciągu ostatnich 20 lat. W drugiej części badania uczestnicy byli proszeni o dokonanie oceny poszczególnych aspektów sytuacji tłumaczeniowej w Polsce: rynku tłumaczeń, edukacji tłumaczy, standardów i jakości tłumaczenia, dostępności, relacji między swoimi środowiskami oraz świadomości środowiska głuchych i słyszącego społeczeństwa na temat thumaczenia PJM.

\subsection{Ttumaczenie języka migowego kiedyś i dziś}

Wszyscy uczestnicy badania zgodnie stwierdzili, że od momentu ich pierwszego zetknięcia się z thumaczeniem w Polsce nastąpiły w tym względzie ogromne zmiany. Część zmian była, zdaniem badanych, zdecydowanie 
pozytywna. Wiele zmian, które wykazywało potencjał, w rzeczywistości nie spełniło oczekiwań bądź też część badanych zauważa ich pozytywne, a część negatywne konsekwencje. Niektóre aspekty tłumaczenia nie uległy zmianie na lepsze, a niektóre się pogorszyły.

\subsubsection{Jest lepiej}

W Polsce, podobnie jak w innych krajach, ,historię tłumaczenia języków migowych można w zasadzie podzielić na dwa główne okresy: przed powstaniem pierwszych organizacji zawodowych tłumaczy języka migowego i po powstaniu tychże" [Kalata-Zawłocka i Łacheta 2012: 227]. Powstanie organizacji zawodowej thumaczy poprzedził zaś wzrost świadomości językowo-kulturowej społeczności Głuchych, któremu towarzyszył podobny wzrost świadomości tłumaczeniowej w środowisku tłumaczy. To one przyczyniły się do powołania do życia Instytutu Polskiego Języka Migowego (IPJM) ${ }^{3}$, pierwszego programu kształcenia tłumaczy PJM (studia podyplomowe „Polski język migowy” działające w latach 20082015 na Wydziale Polonistyki UW) oraz Stowarzyszenia Tłumaczy Polskiego Języka Migowego (STPJM) - organizacji zawodowej tłumaczy PJM. Wzrost świadomości językowo-kulturowej społeczności Głuchych oznaczał odejście od tłumaczenia w systemie językowo-migowym (SJM) ${ }^{4}$ na rzecz naturalnego języka Głuchych $(\mathrm{PJM})^{5}$. Zmiana ta była na tyle

3 Organizacja pozarządowa, która w 2004 roku podjęła intensywne działania mające na celu szerzenie wiedzy na temat polskiego języka migowego [Kalata-Zawłocka 2017].

4 System językowo-migowy (SJM) - sztuczny system komunikacji, w którym znaki migowe, zaczerpnięte częściowo z naturalnego języka Głuchych, artykułowane są według składni języka polskiego. Jest on pozbawiony polisemii i wariantów leksykalnych. Z racji osadzenia w gramatyce języka fonicznego jest łatwiejszy do opanowania dla osób słyszących niż naturalny język migowy, trudniejszy do zrozumienia dla głuchych [Farris 1994]. W latach 60. SJM został wprowadzony przez Polski Związek Głuchych (PZG) do użycia w środowisku osób głuchych, do edukacji głuchych i tłumaczenia.

5 Polski język migowy (PJM) - naturalny język, którym posługują się członkowie polskiej społeczności Głuchych. Powstał na drodze historycznego rozwoju, w wyniku naturalnej potrzeby komunikacji osób, dla których komunikacja za pomocą mowy jest niemożliwa. Posiada własną gramatykę i słownik, odmienne od języka polskiego, wykazuje zróżnicowanie pod względem społecznym i geograficznym. Charakteryzuje się wysoką produktywnością słowotwórczą oraz polisemią, wykazuje cechy typowe dla języków naturalnych: arbitralność, dwuklasowość, produktywność [Świdziński i Gałkowski 2003]. 
istotna, że wspominała o niej w wywiadach większość osób głuchych i tłumaczy (nG=9/nT=9). Można powiedzieć, że był to długo wyczekiwany przełom, w wyniku którego nastąpiło wiele kolejnych zmian, m.in. znacząca poprawa jakości usług tłumaczenia. SJM nie zniknął zupełnie i, jak zauważyło kilkoro badanych, zwłaszcza w mniejszych miejscowościach w Polsce jest wciąż w użyciu.

Jak ja pamiętam, to się thumaczyło systemem. I to był ideał - im bliżej polskiego, tym lepszy był tłumacz. [...] No teraz już tak nie jest, choć rozumiem, że część jednak tak woli. Natomiast w tej chwili zmienił się język, bo teraz jest PJM. (T5)

Wraz ze wzrostem świadomości językowo-kulturowej wśród Głuchych i tłumaczy zmianie zaczęło ulegać rozumienie roli tłumacza. Ponieważ tłumaczenie języka migowego wyrosło na gruncie pomocy społecznej, wolontariatu i asystentury dla osób niepełnosprawnych [Fant 1990; Cokely 2005; Kalata-Zawłocka 2017], przed pojawieniem się w Polsce STPJM w środowisku tłumaczy powszechne było podejście do osób głuchych jako niezdolnych do samodzielnego funkcjonowania. Osoby starsze, mniej samodzielne, nieznające dobrze języka polskiego, przyzwyczaiły się do takiego traktowania. $Z$ czasem jednak nadgorliwą pomoc, wyręczanie i nadopiekuńczość tłumaczy głusi zaczęli odbierać jako ubezwłasnowolniające i upokarzające [Świderski 2011].

[...] w klubie PZG thumacz zawsze był od tego, żeby pomagać: pomóc zadzwonić gdzieś, pomóc załatwić coś w ZUS-ie, pomóc w sprawach życia codziennego. Pomoc, pomoc, pomoc. I zawsze też thumacz był tą osobą, która wie lepiej, jak wesprzeć, jak wyjaśnić. (G3)

Dawniej w różnych instytucjach myślano, że thumaczenie to element pracy socjalnej. A teraz wiadomo, że te dwie sprawy muszą być rozdzielone. Tłumacz to jedno, a pracownik socjalny to drugie. Widać to wyraźnie. (G8)

Dawniej to były inne relacje niż dzisiaj. To były bardziej takie relacje pomagania głuchym, bo głuchemu trzeba napisać, głuchemu załatwić sprawę. Bez nawet informowania go o tym. (G2)

Niektórzy badani podawali przykłady zachowań tłumaczy, które dziś określane są mianem paternalizmu i opresji [Lane 1996; Baker-Shenk 1986; Sacks 1991]: 
Głuchy znajomy mi opowiedział, że na studiach, w czasie ćwiczeń chciał zadać pytanie, a thumacz go uciszał. Pokazywał mu, żeby się nie odzywał. To jest takie myślenie, że głusi mają siedzieć cicho, bo nie mają nic mądrego do powiedzenia. (G6)

[...] były groźby, krytyka, traktowanie głuchych jak dzieci, bo wiedzieli, że nie poniosą za to kary. [...] Wiedzieli, że głusi sobie bez nich nie poradzą, i mieli nad nimi władzę. [...] Byli tłumacze, którzy mimo że dostawali wynagrodzenie za swoją pracę, po cichu i tak kazali sobie głuchym płacić za thumaczenie. [...] Korzystali z tego, że głusi nie mieli świadomości. [...] Kiedyś był w Warszawie taki tłumacz, co za thumaczenie kazał sobie płacić w naturze. (G9)

Jednak z powodu braku innych możliwości komunikacji z otoczeniem, przyzwyczajenia czy bliskich relacji z tłumaczami głusi godzili się na takie traktowanie, obawiali się krytykować tłumaczy, aby ich nie stracić, nie wiedząc, że mogliby mieć wobec nich jakiekolwiek wymagania [Kalata-Zawłocka 2017].

Dzięki powstaniu organizacji zawodowej, która opracowała kodeks etyczny oraz standardy zawodowe, tłumaczenie języka migowego weszło na drogę profesjonalizacji, o której z dużym zadowoleniem mówią zarówno głusi, jak i tłumacze:

Kiedyś, tak jak już mówiłem, thumaczy tu nie było wcale. Ale była tzw. pomoc, asystenci. Teraz jest thumaczenie i tak jest lepiej. (G7)

To, co jest dzisiaj, jest o wiele lepsze. Kiedyś takie zacieśnienie relacji czy przyjaźń to nie było dobre. Bo temu tłumaczowi było szkoda głuchego: „A, nie będę mu mówić, bo po co jego stresować”. Po co? To lepiej połowy rzeczy nie mówić. A teraz tłumacz nie może tego zrobić. Bo jakby ktoś się dowiedział, że on się tak zachowuje, to od razu by wypadł z gry. (G2)

Starsi głusi wciąż potrzebują pomocy i wsparcia. [...] Młode pokolenie już chce być samodzielne. Tłumacz ma być tylko wsparciem komunikacyjnym, pomagać w rozwiązywaniu problemów komunikacyjnych. (G3)

[...] thumacz w końcu dowiedział się, jaka jest jego rola, i stał się thumaczem, a nie jak ja na przykład byłam takim słyszącym, który zrobi wszystko za tego głuchego [...]. Ja po prostu czułam się jak taka wróżka, która zbawia świat. A teraz możemy powiedzieć, że jestem sprowadzona do parteru, z jednej strony, a z drugiej strony jestem w takim bardzo bezpiecznym miejscu, gdzie wiem, co ja mam robić [...]. (T10) 
Głusi nauczyli się też reagować na niepożądane zachowania tłumaczy:

Na jednym z posiedzeń Rady thumaczyła na zastępstwo tłumaczka, którą znam $\mathrm{z}$ tłumaczeń sejmowych. [...] W pewnym momencie coś zamigałem do osoby obok, a thumaczka macha do mnie i miga: „Patrz na mnie”. Ja - szok. Mówię jej: „Przepraszam, ale ja mam prawo rozmawiać”. [...] Po posiedzeniu podszedłem do niej i zapytałem, czy takie zachowanie z jej strony było etyczne. Zdziwiła się. Poprosiłem, żeby się tak więcej nie zachowywała wobec mnie. Nic nie odpowiedziała i poszła. (G6)

CODA mają za dużo przyzwyczajeń. Wyjaśniają wszystko dokładnie. Ja im wtedy mówię: spokojnie, ja studia skończyłem, rozumiem. Nie potrzebuję wyjaśnień od tłumacza. (G8)

Według badanych jest wciąż za mało osób głuchych świadomych takich zachowań związanych z tłumaczeniem. Do tego wielu jest zdania, że „ta zmiana dotyczy przede wszystkim dużych miast. W małych miastach, na wsi, takiej zmiany jeszcze nie ma" (G3). Dlatego też głusi powinni uczyć się tego, na czym polega tłumaczenie, jak właściwie z niego korzystać, jakich zasad powinni przestrzegać thumacze, ale i oni sami, już w trakcie edukacji szkolnej $(\mathrm{nG}=4)$.

Powstanie Kodeksu Etyki STPJM niemal wszyscy uczestnicy badania $(\mathrm{nG}=10 / \mathrm{nT}=10)$ określali jako przełom w sytuacji tłumaczenia języka migowego w Polsce. Wielu głuchych szczególnie podkreślało znaczenie wprowadzonych przez kodeks zasad zachowania tajemnicy zawodowej, bezstronności, profesjonalnego stroju i konieczności doskonalenia zawodowego.

Dawniej to było trudno - czasami jak głuchy bardzo potrzebował thumacza, to zgłaszał się do PZG, bo miał na przykład wizytę u lekarza czy inną sprawę. No to potem ten thumacz rozpowiadał o tym dookoła. Tak nie powinno być. [...] Potem, jak powstało STPJM, zaczęli się uczyć, zaczęło się jakieś przygotowanie, standardy - i bardzo dobrze. Tak powinno być. (G7)

Dawniej jak głuchy przychodził, żeby tłumacz gdzieś zadzwonił, to najpierw wszystko thumaczowi opowiedział, a potem thumacz dzwonił i sam rozmawiał. Jak skończył rozmawiać, dopiero wyjaśniał głuchemu, co załatwił. Dla głuchego to było super, ale ja czasami się wkurzałam, bo tłumacz odłożył słuchawkę, a ja miałam jeszcze jakieś pytania. [...] Jak się przerywało tłumaczowi i pytało, co mówi osoba słysząca, to tłumacz uznawał, że głuchy jest 
wścibski. [...] Zmiany duże nastąpiły, jeśli chodzi o neutralność tłumacza dawniej tłumacz rządził, a głuchy się go słuchał. (G10)

Dwoje głuchych badanych zauważyło, że zmiana świadomości głuchych odnośnie do roli tłumacza i pojawienie się kodeksu etyki pociągnęły za sobą zmianę podejścia osób głuchych do korzystania w tłumaczeniu z pomocy swoich słyszących dzieci (CODA):

Dawniej, jak się głuchym rodziło dziecko słyszące, od małego przyzwyczajali je do bycia ich tłumaczem aż do śmierci. Teraz głusi wiedzą, że małe dziecko nie powinno być thumaczem. Już nie uczą migać, zmuszają, żeby mówiło, że lepiej słyszeć, iść do szkoły. [...] Mój dziadek mówił do mojej mamy: „Słysząca jesteś, będziesz moim thumaczem”. Więc mama szła tłumaczyć, koniec kropka. (G10)

Tłumacze również podkreślali niezwykle istotny wpływ zasad etycznych i standardów zawodowych na jakość ich pracy, komfort, satysfakcję i poczucie bezpieczeństwa klientów. Szczególną uwagę zwracali, podobnie jak głusi badani, na zasadę poufności i bezstronności, ale też na zasadę pracy w parze lub zespole (ang. team interpreting) i potrzebę odpowiedniego stroju:

[tłumaczka do klienta - A.K.-Z.] [...] ,proszę się nie martwić, ja mam certyfikat PZG, ale też należę do STPJM, gdzie obowiązują pewne zasady. Do tych zasad należy pełne zaufanie, to znaczy to, co wchodzi do moich uszu, zostaje tam, ja to zapominam, wychodzę z thumaczenia i w ogóle już tego nie używam”. No i oni się dziwią, no bo niestety, standardem do tej pory było, że thumacz słyszał i klepał, i dalej to szło. (T4)

[...] przede wszystkim praca w teamie - to był przełom. Bo jak ja zaczynałam pracować, to pamiętam takie sytuacje, naprawdę, i przyznaję się bez bicia, że tłumaczyłam i 6 godzin sama jakieś wydarzenie. Ja po prostu nie miałam świadomości takich rzeczy wtedy. I teraz, jak jest jakieś wydarzenie, to już nie tylko team thumaczy, tylko cały zespół tłumaczy. (T7)

Za diametralną zmianę w związku z tłumaczeniem wszyscy badani uznali pojawienie się nowych sytuacji, w których zaczęły być wykonywane tłumaczenia. Wraz z wejściem w życie nowych aktów prawnych dotyczących funkcjonowania osób niepełnosprawnych ${ }^{6} \mathrm{~W}$ społeczeństwie

$6 \quad$ Ustawa o zmianie ustawy - Prawo o szkolnictwie wyższym, ustawy o stopniach naukowych i tytule naukowym oraz o stopniach i tytule w zakresie sztuki oraz o zmianie 
przed przedstawicielami środowiska głuchych otworzyły się nowe sfery życia społecznego: „Tłumaczenia jest coraz więcej. Dawniej tłumacze byli zatrudniani tylko w sprawach prywatnych i byli w telewizji”. (G3)

To, co się zmieniło, to na pewno thumaczenie w telewizji, [...] thumaczenia na uczelniach - to dla mnie był taki szok chyba. Sprawy urzędowe - w urzędzie jesteś $\mathrm{w}$ stanie skorzystać $\mathrm{z}$ obecności thumacza. Tłumaczenia $\mathrm{w}$ teatrze i cała kultura - teatr, kino, to na pewno. Konferencyjne thumaczenia też - to jeszcze chyba było przed tym thumaczeniem w kulturze. Pojawienie się thumaczy w kampaniach społecznościowych, reklamach. [...] thumacze stają obok prezydenta na tych wszystkich briefingach prasowych, premiera, samorządowców, też rządu. Pojawienie się thumaczy w bajkach. W telewizji, ale też w Internecie. Teraz to, co się dzieje, czyli wszelkiego rodzaju szkolenia, webinaria, spotkania, wywiady. Thumaczenie online [...], thumaczenie rad miasta, thumaczenie muzyki, koncerty, poezja". (T7)

W nowo dostępnych obszarach głusi zaczęli coraz chętniej aktywnie zaznaczać swoją obecność w różnego rodzaju wydarzeniach w roli prelegentów, organizatorów, działaczy, przedsiębiorców. Zaczęli zatem potrzebować thumaczenia $\mathrm{z}$ języka migowego na foniczny.

[...] zaczęliśmy tłumaczyć na foniczny. To kolejny przełom. Uważam, że jest, bo głusi zaczęli być bardziej aktywni, wcześniej thumaczenia na przykład konferencyjne czy jakichś spotkań były wykonywane tylko w jedną stronę. (T7)

niektórych innych ustaw (Dz.U. $2011 \mathrm{nr} 84$ poz. 455) nałożyła na uczelnie wyższe obowiązek stworzenia studentom niepełnosprawnym warunków do pełnego udziału w procesie kształcenia, m.in. poprzez zapewnienie im usług thumaczenia języka migowego; Ustawa o języku migowym i innych środkach komunikowania się (Dz.U. 2017 poz. 1824) zobligowała urzędy do udostępnienia świadczonych przez siebie usług osobom głuchym w wybranej przez nie formie komunikacji; Ustawa o zmianie ustawy o radiofonii i telewizji z 2018 roku (Dz.U. 2018 poz. 915) i Rozporzadzenie Krajowej Rady Radiofonii i Telewizji (KRRIT) w sprawie udogodnień dla osób niepetnosprawnych z powodu dysfunkcji narządu wzroku i osób niepetnosprawnych z powodu dysfunkcji narzadu stuchu w programach telewizyjnych z tego samego roku (Dz.U. 2018 poz. 2261) wprowadziły obowiązek zwiększenia przez stacje telewizji publicznej liczby programów emitowanych z tłumaczeniem na język migowy; Ustawa o zapewnianiu dostępności osobom ze szczególnymi potrzebami (Dz.U. 2019 poz. 1696) nakłada na podmioty publiczne obowiązek zapewnienia osobom ze szczególnymi potrzebami dostępności do oferowanych przez siebie usług poprzez m.in. tłumaczenie na język migowy np. w urzędach i w bankach. 
Początkowo tłumacze nie mieli takich umiejętności, żeby przetłumaczyć głuchego na język foniczny. Do tej pory tłumaczyli głównie w jedną stronę na PJM, czy raczej na SJM. (G12)

\subsubsection{Lepiej, ale nie do końca}

Pojawiły się rozwiązania techniczne i administracyjne ułatwiające głuchym korzystanie z usług thumaczenia. Dzięki nowym technologiom komunikacyjnym możliwe stało się m.in. tłumaczenie na odległość (ang. remote interpreting), które w istotny sposób zwiększyło udział osób głuchych w życiu społecznym [Kalata-Zawłocka 2019]. Taki rodzaj tłumaczenia oferuje w tej chwili kilka firm i kilka organizacji pozarządowych w różnych częściach kraju. Szczególnie chętnie korzystają z niego osoby młodsze $(\mathrm{nG}=3)$. Trudniej jednak przekonać się do niego osobom starszym oraz, co zrozumiałe, nieposiadającym odpowiedniego sprzętu. Ponadto, jak o tłumaczeniu online stwierdził jeden z badanych:

[...] wielu głuchych tego nie lubi, bo nie wiedzą, kto będzie tłumaczył - nie znają thumacza, nie wiedzą, jak będzie migał. Na przykład w Polsce są dwie-trzy firmy thumaczeniowe online. Na ich stronach są zdjęcia thumaczy, ale ja bym chciał zobaczyć, jak oni migają, a tam nie ma filmików. (G11)

Choć niewielu badanych $(\mathrm{nG}=3 / \mathrm{nT}=3)$ o tym wspomina, dzięki rozporządzeniu określającemu rodzaje zadań powiatu, które mogą być dofinansowane ze środków Państwowego Funduszu Rehabilitacji Osób Niepełnosprawnych (PFRON), wydanemu do Ustawy o rehabilitacji zawodowej i społecznej oraz zatrudnianiu osób niepetnosprawnych (Dz.U. 2019 poz. 1172), głusi zyskali możliwość zdobycia dofinansowania usług tłumaczeniowych np. u lekarza, które wcześniej często musieli pokrywać z własnych środków. Póki co, nie jest to jednak rozwiązanie idealne ani dla głuchych, ani dla tłumaczy:

Myślę, że to też jest ważne, że klient nie płaci, ale państwo. Ja uważam, że wszyscy powinni jednak zwracać się do tego WCPRu [...]. Z drugiej strony minusem jest to, że trzeba mieć swoją działalność gospodarczą. Ja myślę, że to eliminuje dużą liczbę osób. (T6)

[...] miałem problem, żeby złożyć wniosek - 10 stron wypełniania, żeby dostać dofinansowanie! Nie wiem, może teraz to się zmieniło, ale pamiętam, jak kiedyś w mieście $X$ składałem wniosek, to jeszcze trzeba było załączyć 
audiogram i zaświadczenie, że jestem głuchy. Potrzebowałem ze 3 dni, żeby to wszystko załatwić! (G4)

Świadomość istnienia kodeksu etyki i standardów zawodowych obowiązujących tłumaczy PJM ośmieliła głuchych do wyrażania swojego zdania na temat tłumaczenia. Zarówno głusi, jak i tłumacze uważają, że to kolejny krok naprzód: „To, że głusi mają odwagę, to chyba jest lepsze, chociaż to nas bardziej może dotyka, to to jest lepsze. Mają swoje prawo, my jesteśmy dla nich" (T3). Jednak zarówno badani tłumacze (n=9), których pracy dotyczą opinie ich głuchych odbiorców, jak i niektórzy badani odbiorcy $(\mathrm{n}=4)$ wyrażali przekonanie, że ton wypowiedzi oceniających jakość pracy tłumaczy bywa niekiedy zbyt ostry, wręcz obraźliwy. Za niewłaściwe badani uznawali też to, że do wymiany opinii o thumaczeniu dochodzi często w przestrzeni publicznej, np. w mediach społecznościowych. Tak tłumacze, jak i głusi podkreślali, że nie służy to budowaniu dobrych relacji między środowiskami: ,zadziwia mnie, że teraz głusi w całej Polsce się obudzili, ale przesadzają, za mocno” (G10), „Muszą się też nauczyć, jak dawać thumaczom feedback, bez urywania im głowy" (G5). Ich zdaniem opinię dotyczącą tłumaczenia należałoby przekazać konkretnemu tłumaczowi prywatnie i w formie konstruktywnej krytyki:

Oni mówią wprost i bezpośrednio, i też się muszą nauczyć, jak dawać feedback konkretny, bo nie sztuką jest zjechać tego thumacza od dołu do góry, że on się nie podniesie później. (T9)

Na pewno bym nie krytykował thumaczy. Na pewno nie publicznie. Może prywatnie bym zwrócił uwagę, ale nie publicznie. Jeśli taka ta krytyka będzie publiczna, to dużo thumaczy będzie rezygnować z tłumaczenia. (G8)

Więcej obszarów tłumaczenia i uregulowania prawne sprzyjają dostępowi osób głuchych do informacji, wiedzy i życia słyszącego społeczeństwa. Badani z obu grup zdecydowanie podkreślali to w swoich wypowiedziach:

[...] teraz myślę, że jest super. Naprawdę jest mnóstwo wydarzeń dostępnych, tylko nie każdy ma czas je oglądać. Myślę, że głuchy miałby teraz co robić przez 24 godziny, jakby chciał dzień w dzień oglądać to, co jest tłumaczone. (T9)

Jednakże w toku badania okazało się, że pojęcie dostępności może być rozumiane $\mathrm{z}$ jednej strony jako dostępność informacji, edukacji, usług, 
dóbr kultury i sfery społecznej - tutaj widoczny wzrost dostępności nastąpił po wprowadzeniu wspomnianych wyżej regulacji prawnych i rozwiązań administracyjnych, dzięki któremu głusi mogą korzystać z usług tłumaczenia w urzędzie, u lekarza, w muzeum, na uczelni wyższej, dlatego częściej widzimy tłumacza w telewizji, na webinariach czy szkoleniach w Internecie. $Z$ drugiej strony, dostępność wynika z faktycznej możliwości skorzystania $\mathrm{z}$ thumaczenia. Badani z obu grup mieli podobne spostrzeżenia co do tego, jak bardzo te dwie kwestie nie idą ze sobą w parze. Często bowiem okazuje się, że dostępności nie ma z powodu niewystarczającej liczby thumaczy:

[...] w szkołach dla słyszących jest problem. [...] Na przykład gdy są zebrania rodziców. Tu w mieście $\mathrm{X}$ jest tak, że zebrania w szkołach są często tego samego dnia: w podstawówkach, zawodówkach. A PZG ma tylko 5 tłumaczy. I jak oni sobie mają z tym poradzić? No więc, kto pierwszy, ten lepszy. (G8)

$\mathrm{Z}$ dostępnością w ogóle jest raczej słabo. Ja bardzo często biorę udział w szkoleniach i warsztatach, i wiem, że bardzo często nie ma zapewnionego thumaczenia. Czasami biorę thumacza prywatnie, ale to nie wystarcza. (G10)

[...] dostępność to jedna sprawa, druga to dostępność w sensie technicznym. Na przykład OK, teatr jest, w teatrze tłumacz, ale jak głusi przyjdą, to muszą siedzieć w pierwszym i drugim rzędzie, żeby widzieć thumacza. W takiej sytuacji to ja się czuję jak dziecko na wycieczce szkolnej - pani wprowadza dzieci i każe siadać blisko thumacza. Dostępność to jest wtedy, gdy jestem traktowany na równych zasadach. Słyszący sobie wybierają miejsce, ja też chcę. Ja na przykład lubię siadać na końcu. (G11)

Wielu badanych zwracało także uwagę na to, że dostępność nie wynika z samej obecności tłumacza, a z jakości jego pracy:

Na przykład w MZON na Andersa podobno jest thumacz, ja tam poszedłem, a tam jakieś machanie rękami... To ja szybciej się dogadałem, mówiąc na głos, niż z takim thumaczem. (G9)

W TV thumacz jest mały albo go nie ma, albo, tak jak na konferencji ministra zdrowia, thumacz najpierw jest, a potem znika. (G3)

Jest kilka osób, które tłumaczą w telewizji, i ja nie mogę ich zrozumieć, na przykład. Pytam mamę: „Ty oglądałaś. Co myślisz?”. Trochę rozumiem, tak połowę odbieram, ale lepiej on niż wcale. (G2)

Dzisiaj oglądałem przez chwilę TVN24 i był tam thumacz. [...] Tłumaczenie nawet OK, ale za dużo było dookoła napisów, belek, wszystko to 
przeszkadzało w odbiorze thumaczenia. Aż oczy bolały. Nie wiadomo było, gdzie patrzeć. Ciężko się było skupić. (G4)

Jeszcze inną kwestią jest to, jak instytucje i firmy podchodzą do obowiązku zapewniania dostępności:

W pracy nadal mam problem - na przykład gdy jest szkolenie BHP i proszę o tłumacza, to nie chcą zatrudniać thumacza, bo nie chcą płacić. (G7)

[...] jeśli chodzi o thumaczenia na uczelni, nadal długie godziny thumacze pracują w pojedynkę. Więc tu to nie jest zupełnie przestrzegane. (T7)

Ustawa o PJM niby jest, ale na przykład ostatnio w urzędzie nie mogłam się dogadać z panią, pisałam jej na kartce, że potrzebuję tłumacza, to podarła tę kartkę. (G5)

Mimo iż rozmiar tłumacza na ekranie jest dla głuchych widzów jednym z głównych warunków dostępności, jeśli chodzi o utwory audiowizualne, a w 2020 roku Monika Szczygielska i Aleksandra Kalata-Zawłocka opracowały wytyczne dotyczące m.in. rozmiaru i umiejscowienia thumacza PJM w materiałach transmitowanych przez stacje telewizyjne i organizatorów wydarzeń streamowanych do Internetu ${ }^{7}$, wypowiedzi badanych nie pozostawiają wątpliwości co do realizacji ich prawa do dostępności: „Mam wadę wzroku i nie mogę na tego małego tłumacza patrzeć cały czas” (G1), „Pamiętam, jak z okazji Święta Niepodległości był koncert i tłumacz w trakcie koncertu zaczął się zmniejszać. No co to jest? Przykro. Nie wiem, dlaczego tak zrobili” (G7). Żal i frustrację zarówno środowiska głuchych, jak i tłumaczy, którzy wspierają ich w walce o pełną dostępność, dobrze oddaje wypowiedź jednej z badanych:

Czasem jest tak: zrobimy okienko na tyle małe, żeby się nie czepiali, ale żeby nie przesadzić. Bierzemy thumacza, ale jednego, damy okienko, ale malutkie. Weźmiemy tego tłumacza, nieważne, że on migał wszystko na prawą rękę, i walniemy go z lewej strony, będzie nie tak, ale nieważne, na zewnątrz będzie wyglądać, że jest. Każą mieć tłumacza, to będzie, nawet jeśli lewitujący. (T2)

7 „Wytyczne na czas kryzysu w sprawie sposobu realizacji i jakości tłumaczeń na język migowy w utworach audiowizualnych" <https://avt.ils.uw.edu.pl/files/2020/03/ Dost $\%$ C4\%99pno\%C5\%9B\%C4\%87-pjm-wytyczne-na-czas-kryzysu.pdf $>$, dostęp 8.01.2021. 
Świadomość słyszącej części społeczeństwa, a zwłaszcza jej tendencja wzrostowa, została doceniona przez wszystkich badanych. Zdanie, które najczęściej padało w wywiadach, brzmiało: „Jest lepiej”.

Taki przeciętny słyszący człowiek coraz więcej wie na temat tłumaczenia, mało tego, spotykam klientów, którzy mówią mi na przykład: „Ale tłumaczy dwóch i proszę się ubrać tak i tak". Wiadomo, jest jeszcze 50\% takich, co by chcieli jednego na cały dzień, ale kiedyś w ogóle nie było o tym mowy. (T8)

$\mathrm{Z}$ drugiej strony, przedstawiciele środowiska tłumaczy PJM wciąż skarżą się na to, że ich status zawodowy jest niższy niż status ich kolegów-tłumaczy języków fonicznych:

Nikt nie myśli w kategoriach, że to są jakieś dwa języki, tylko jakiś kod dla Polaków przecież niepełnosprawnych. To są cały czas Polacy, którym ja muszę to wszystko jakoś tak powiedzieć... My, w mojej ocenie, w tej społecznej percepcji nie trafiamy ludziom do tej szufladki z napisem „thumacz”. Oni nas nie traktują cały czas jako thumaczy. (T2)

Widać to również m.in. w określeniach takich jak „migaczka” czy „pani od języka migowego”, która „skradła show” albo „wygrała debatę prezydencką", używanych przez słyszących. Entuzjastyczne przyjęcie tłumaczenia PJM ze strony słyszących widzów samo w sobie nie jest niczym złym, ale określenia użyte do jego wyrażenia badane thumaczki uznały za deprecjonujące.

Ciągle się trzeba upominać, żeby dziennikarze mówili: thumacze. Nawet ci z tego ministerstwa, co ostatnio thumaczyłyśmy, ta dziewczyna, co robi napisy, napisała taką notkę do przekazania, którą widziałyśmy, tam było napisane: „proszę, przekaż migaczkom”. „Tłumacze, thumaczki” to chyba wszystkich w ogóle boli, żeby to przeszło przez usta, żeby to powiedzieć. (T6)

[...] nie można naszej pracy wykorzystywać po to, żeby dać ludziom atrakcję. Ja nie jestem tą, co na rurze tańczy. To jest język! (T8)

Jako wysoce niezadowalającą, mimo obowiązującej wspomnianej już Ustawy o dostępności, badani określają $(\mathrm{nG}=7 / \mathrm{nT}=8)$ świadomość różnego rodzaju instytucji i urzędów:

Ostatnio była taka sytuacja, że na jakimś tam forum pani szukała 2-3 tłumaczek, kursantów języka migowego. Jakaś organizacja na jakieś webinarium, 
jakąś debatę. Szukała absolwentów kursów migowych, takich osób, które się uczą, dopiero skończyły, są na kursach. (T10)

[...] mają na to przyzwolenie, że mogą w ten sposób podejść. Bo jakby organizowali konferencję języka angielskiego, toby nie pomyśleli o tym, żeby wziąć mnie, która od 15 lat jest na B1 albo już nawet na A0. Nie ma takich pomysłów. (T8)

[...] dyskryminacja jest nadal. Przede wszystkim w urzędach i z tym pisaniem, że my tu sobie z głuchym popiszemy. Taka niewiedza. (T11)

Raz to miałam nawet awanturę w urzędzie, bo pani w okienku, jak zapytałam o thumacza, to mi powiedziała, że co ja wymyślam! (G10)

\subsubsection{Jest źle lub gorzej}

Mimo że w ujęciu ogólnym zarówno badani głusi, jak i thumacze przyznają, iż sytuacja tłumaczenia języka migowego w Polsce uległa znaczącej poprawie, pod niektórymi względami nic się nie zmieniło albo jest wręcz gorzej. Badani ( $\mathrm{nG}=8 / \mathrm{nT}=9)$ wskazywali na dramatyczny obecnie brak edukacji dla tłumaczy PJM. W latach 2008-2015 na Wydziale Polonistyki UW funkcjonowały studia podyplomowe dla lektorów i tłumaczy PJM, do niedawna również Stowarzyszenie Tłumaczy Języka Migowego zapewniało szkolenia, warsztaty i konferencje (obecnie, w związku z nastaniem pandemii, nastąpił chwilowy przestój edukacyjny). Jest to niepokojące ze względu na niewystarczającą liczbę thumaczy aktywnych zawodowo i brak dopływu nowych tłumaczy, którzy by pomogli wypełnić lukę na rynku pracy. Filologia polskiego języka migowego na UW, którą w roku 2021 ukończy pierwsza grupa studentów, nie przygotowuje do wykonywania zawodu thumacza, studia na kierunku lingwistyka stosowana, które przygotowują, dopiero w 2020 roku przyjęły pierwszych studentów z PJM w swojej kombinacji językowej. Bardziej doświadczeni tłumacze PJM skarżą się też na brak możliwości doskonalenia zawodowego:

Ja bym chciała, żeby była jakaś taka szkoła wieczorowa albo zaoczna dla thumaczy takich jak ja, bo ja odczuwam straszny smutek z tego powodu, że nie mogę uczestniczyć w tych studiach lingwistycznych. (T3)

Mi się marzy też taka struktura pozaformalna, studia oczywiście jak najbardziej tak, ale z perspektywy osób, które nie są w wieku studyjnym, ja bym chciała mieć dostęp do szkoleń. Chciałabym mieć cykliczny dostęp do tego, że mogę się kształcić na przykład językowo. (T1) 
W dalszej kolejności brakuje, zdaniem badanych $(n=8)$, kontroli jakości tłumaczeń, które są obecnie dostępne. Dotychczas istniejące certyfikaty wydawane przez PZG nie mają charakteru państwowego, projekt certyfikacji zaś opracowany przez STPJM we współpracy z Instytutem Badań Edukacyjnych w formie kwalifikacji rynkowej od 2019 roku nie został zatwierdzony przez Ministerstwo Pracy, Rodziny i Polityki Społecznej.

Wszyscy głusi badani wyrażali też zaniepokojenie tym, że tłumacze PJM mają zbyt mały kontakt $\mathrm{z}$ ich środowiskiem. Jak wyjaśnia jedna z osób badanych:

A ja uważam, że to jest bardzo potrzebne. Dzięki kontaktowi z głuchymi, uczestnictwie w ich życiu codziennym, tłumacze się rozwijają pod względem językowym. I przychodzi im to bardzo łatwo. Łatwiej im też dzięki temu zrozumieć sposób myślenia głuchych, ich zachowania. (G3)

Zdaniem 9 badanych jest to jedna z przyczyn tego, że

wielu głuchych nie do końca rozumie tłumaczy. Tak, muszą się do nich dostosowywać. Tłumaczenie jest już na wysokim poziomie, ale ciągle czegoś brakuje, żeby było idealnie. [...] Gdyby thumacze byli bliżej głuchych, rozumieliby, dlaczego głusi nie ufają thumaczom. (G3)

Ów „kontakt z głuchymi”, o którym wspominali badani, nie oznacza konieczności zadzierzgania zażyłych relacji personalnych tłumaczy z głuchymi, a raczej potrzebę bycia na bieżąco $\mathrm{z}$ wydarzeniami w środowisku oraz bezpośredni kontakt z żywym językiem, który jest niezwykle istotny z powodu silnego zróżnicowania wewnętrznego języka migowego i braku jego standaryzacji [Farris, 1994; Lucas i Valli, 1992] oraz materiałów do nauki języka. Nieznajomość różnych form i stylów komunikacji osób głuchych, nieświadomość zmian leksykalnych wynikających z rozwoju języka skutkuje trudnościami odczuwanymi przez tłumaczy w rozumieniu wypowiedzi w języku migowym [Kalata-Zawłocka, 2017]. Jak wyjaśniła jedna z osób badanych (G12), chodzi o to, aby kontakt tłumacza z językiem migowym nie ograniczał się wyłącznie do pracy w telewizji, a miał też miejsce w rzeczywistych sytuacjach komunikacji z głuchymi.

\subsubsection{Thumaczenie w czasie pandemii}

Z rozmów z badanymi wynika, że pandemia COVID-19, podobnie jak w przypadku wielu innych środowisk, odcisnęła piętno na środowiskach tłumaczy PJM i osób głuchych. Możliwości komunikacyjne głuchych 
uległy znacznemu pogorszeniu z uwagi na konieczność noszenia maseczek oraz wymuszonego kontaktu telefonicznego $\mathrm{z}$ większością urzędów $\mathrm{i}$ instytucji. W początkowym okresie pandemii głusi borykali się z brakiem thumaczeń informacji dotyczących strategii władz kraju w walce z chorobą. Stopniowo ich sytuacja zaczęła się poprawiać, liczne protesty poskutkowały $\mathrm{m}$.in. pojawieniem się thumaczenia kolejnych zaleceń i restrykcji ogłaszanych przez władze, dzięki staraniom PZG zostały uruchomione usługi online thumaczenia spraw związanych z COVID-19, kolejne urzędy i instytucje zaczęły umożliwiać ze sobą kontakt za pośrednictwem thumaczenia na odległość.

Tłumacze, po początkowym załamaniu się rynku tłumaczeniowego spowodowanym brakiem możliwości bezpośredniego kontaktu z klientami (odwołane zajęcia na uczelniach, zamknięte urzędy, instytucje kultury, brak możliwości organizacji wydarzeń), obecnie przeżywają natłok zleceń, spowodowany przeniesieniem się większości z nich do Internetu. Według badanych konieczność przestawienia się praktycznie całkowicie na pracę na odległość zaowocowała możliwością współpracy z koleżankami/kolegami z całej Polski. Dostępność wielu tłumaczonych wydarzeń w Internecie spowodowała jednak nasilenie się wzajemnej krytyki w środowisku tłumaczy, a gwałtowny wzrost liczby zleceń przy niewystarczającej liczbie tłumaczy prowadzi do obniżenia jakości tłumaczeń (np. brak thumaczy do wykonania thumaczenia w teamie, przemęczenie, wykonywanie tłumaczeń przez osoby nieposiadające odpowiednich kompetencji). Zakaz organizacji wydarzeń istotnie ograniczył tłumaczom możliwości podnoszenia kwalifikacji.

\section{Wnioski}

Wypowiedzi tłumaczy PJM oraz osób głuchych zebrane w badaniu potwierdzają, że od wielu lat obserwujemy w Polsce powolny proces profesjonalizowania się zawodu tłumacza PJM [por. Kalata-Zawłocka 2017]. Pod wieloma względami dla obu grup oznacza to znaczącą poprawę w stosunku do tego, co znali z czasów dzieciństwa, młodości czy choćby sprzed kilku lat. Oprócz tego, co zostało już wspomniane wcześniej, czyli zastąpienia SJM przez PJM, pojawienia się nowych obszarów i sposobów tłumaczenia (z PJM na język polski, w teamie, online), możliwości edukacyjnych dla tłumaczy, regulacji prawnych, powstania organizacji zawodowej tłumaczy i kodeksu etyki, badani zwracali uwagę na to, że 
zaczęto wykonywać tłumaczenia między językiem angielskim a PJM $(\mathrm{nG}=1 / \mathrm{nT}=4)$ oraz PJM a International Sign $(\mathrm{IS})^{8}(\mathrm{nG}=3 / \mathrm{nT}=4)$. Niektórzy $(\mathrm{nG}=2 / \mathrm{nT}=6)$ zauważyli też, że dzięki członkostwu STPJM w Europejskim Forum Tłumaczy Języka Migowego, środowisko tłumaczy nawiązało kontakt z tłumaczami z zagranicy i powstała grupa głuchych tłumaczy. Wciąż jednak głusi borykają się z wieloma barierami utrudniającymi im codzienne funkcjonowanie, takimi jak brak tłumaczeń, tłumaczenia niskiej jakości, zbyt mały rozmiar tłumacza w telewizji itp.

W kontekście realizacji prawa osób głuchych do dostępu do informacji, wiedzy i życia społecznego badani mówią o dostępności pozornej. Nie w pełni skuteczne rozwiązania prawne nie pomagają niwelować nierówności społecznych, a brak powszechnej edukacji społecznej na temat Głuchych jako mniejszości językowo-kulturowej przyczynia się do ich nieustającej dyskryminacji (konieczność posługiwania się pisaną polszczyzną zamiast PJM, brak tłumaczenia na PJM ważnych oficjalnych informacji podawanych w mediach w czasie pandemii itp.). Braki systemowe, takie jak brak edukacji tłumaczy i kontroli jakości ich pracy, utrudniają postrzeganie tłumaczy PJM jako profesjonalistów. Do dziś tłumacze PJM nie mogą uzyskać, tak jak tłumacze języków fonicznych, statusu tłumaczy przysięgłych, lecz jedynie biegłych sądowych, a duża część społeczeństwa traktuje ich jak dodatkowe urozmaicenie wydarzeń publicznych.

\section{Podsumowanie}

Za podsumowanie niech posłużą wybrane wypowiedzi badanych, zapytanych o to, jak - w odniesieniu do tłumaczenia PJM - wyobrażają sobie sytuację idealną:

Chciałbym nie musieć się martwić, czy tłumacz mnie rozumie, czy nie rozumie, i żeby on bez problemu mnie thumaczył. I też chciałbym, żeby thumacz thumaczył, dostosowując poziom swojego języka polskiego do poziomu mojej wypowiedzi migowej. Ładnie i poprawnie, żeby umiał wychwycić ironię. (G11)

$8 \quad$ International Sign(s) (International Sign Pidgin) - międzynarodowy system znaków służący do komunikacji między przedstawicielami społeczności Głuchych z różnych krajów, wykorzystywany w sytuacjach kontaktów międzynarodowych, takich jak Deaflympics, wybory Miss i Mistera Głuchych, konferencje, sympozja, szkolenia [McKee i Napier 2002]. 
Chciałabym, żeby tłumaczy było więcej. Żeby życie było normalne, żeby można było sobie wybrać tego thumacza i załatwiać swoje sprawy. Żeby nie było tak, że jak nie uda mi się znaleźć tłumacza, to nie mogę załatwić, co mam do załatwienia. (G3)

Marzy mi się dostępność thumaczy 24 h na dobę. (G8)

[...] żeby każda telewizja miała tłumacza, $[\ldots]$ żeby każdy urząd, do którego zgłasza się głuchy, miał na wyposażeniu cały czas thumacza i żeby głuchy nie musiał się prosić z trzydniowym wyprzedzeniem, że przyjdzie i będzie chciał załatwić jakąś sprawę. (T10)

Marzy mi się pójść do teatru i żeby było tam 100-procentowe thumaczenie, żebym sama nie musiała załatwiać tego thumaczenia, sprawdzać, czy jest, tylko żebym poszła i żeby było. Albo marzy mi się pójść na koncert z thumaczeniem przygotowanym i dopasowanym do muzyki. Po prostu życie bez barier. I w ogóle jeszcze marzę o takim swoim tłumaczu na stałe. Może nie 24 godziny na dobę, ale żebym nie musiała szukać i się martwić za każdym razem, kiedy muszę gdzieś zadzwonić. (G11)

Chciałabym też, aby głusi już w szkole uczyli się, jak korzystać z usług thumacza. Żeby się uczyli, jakie mają prawa i jak walczyć o dostępność. [...] Żeby urząd nie obwiniał głuchego o to, że nie załatwił sobie tlumacza. Żeby głusi mieli taką podstawową wiedzę o tym, jak dbać o swoje sprawy, sprawy dostępności, tłumaczenia, żeby mieli świadomość w tym zakresie. (G5)

[...] żeby był wielki thumacz w TV, żeby była taka możliwość włączenia i wyłączenia tłumacza, jak napisy. (G12)

[...] żebyśmy byli traktowani na równi z thumaczami języków fonicznych. Bo cały czas nas się wiąże z niepełnosprawnymi. [...] Chciałabym, żeby nas naprawdę traktowali poważnie, a nie że jesteśmy tylko migaczami, którzy machają rękami. Bo my naprawdę pracujemy głową, a ręce to są tylko nasze narzędzia. (T7)

[...] żeby głusi tłumacze byli bardziej widoczni. (G2)

Z wypowiedzi osób uczestniczących w badaniu, zwłaszcza tych zacytowanych powyżej, płynie jeden główny wniosek: dla pełnego funkcjonowania osób głuchych w społeczeństwie konieczne jest zapewnienie im tłumaczenia zawsze i wszędzie tam, gdzie tego potrzebują. Tłumaczenia wysokiej jakości. Nie z łaski, a ze zrozumienia potrzeb Głuchych jako mniejszości językowo-kulturowej. Słysząca część polskich obywateli nie musi marzyć o możliwości porozumiewania się w swoim pierwszym 
języku we własnym kraju. „Byłoby cudownie, gdyby wreszcie uznać gluchych za obywateli RP”. (T2)

\section{Bibliografia}

Baker-Shenk, Ch. (1986), „Characteristics of Oppressed and Oppressor Peoples: Their Effect on the Interpreting Context", [w:] Marina L. McIntire, red. PROCEEDINGS OF THE 1985 RID CONVENTION. Interpreting: the Art of Cross-Cultural Mediation. San Diego, California: RID Publications.

Bélanger, D.C. (1998), „De l'analyse à la préservation de l'équilibre d'interprétation", [online] https://www.academia.edu/15987281/Les_sp\%C3\%A9cificit $\% \mathrm{C} 3 \% \mathrm{~A} 9 \mathrm{~s}$ _de_linterpr\%C3\%A9tation_en_langue_des_signes_qu $\% \mathrm{C} 3 \% \mathrm{~A}-$ 9b\%C3\%A9coise, dostęp 9.01.2021.

Cokely, D. (2005), „Shifting Positionality: A Critical Examination of the Turning Point in the Relationship of Interpreters and the Deaf Community", [w:] Marc Marschark, Robert Peterson, Elisabeth Winston, red. Sign Language Interpreting and Interpreter Education, New York, Oxford University Press: 208-234, https://doi.org/10.1093/acprof/9780195176940.003.0001.

Fant, L. (1990), Silver Threads. A Personal Look at the First Twenty-five Years of the Registry of Interpreters for the Deaf, Silver Spring, MD: RID Publications.

Farris, M.A. (1994), „Sign Language Research and Polish Sign Language”, Lingua Posnaniensis XXXVI: 13-36.

Frishberg, N. (1990), Interpreting: An Introduction, Silver Spring: RID Publications.

Kalata-Zawłocka, A. (2019), „(Nie)obecność tłumacza w tłumaczeniu języka migowego - wyzwania komunikacji na odległość", [w:] Ewa Gruszczyńska, Małgorzata Guławska-Gawkowska, Anna Szczęsny, red. Translatoryczne i dyskursywne oblicza komunikacji, Instytut Lingwistyki Stosowanej UW, Warszawa: 185-203.

Kalata-Zawłocka, A. (2003), „Tłumacz w świecie ciszy - wokół zagadnień dotyczących thumaczenia migowego", Lingua Legis. 11: 19-30.

Kalata-Zawłocka, A. (2017), Społeczne i językowe konteksty thumaczenia języka migowego w Polsce. Warszawa, Wydawnictwo Wydziału Polonistyki UW.

Kalata-Zawłocka, A., Łacheta, J. (2012), „Profesjonalny thumacz języka migowego - a kto to taki?", [w:] Małgorzata Guławska-Gawkowska, Krzysztof Hejwowski, Anna Szczęsny, red. Tłumacz: sługa, pośrednik, twórca?, Warszawa, Sowa Sp. z o.o.: 223-233. 
Kellet-Bidoli, C.J. (2001), „Spoken-Language and Signed-Language Interpretation. Are They Really So Different?", [w:] Giulia Garzone, Maurizio Viezzi, red. Interpreting in the 21st Century: Challenges and Opportunities, John Benjamins: $171-179$, https://doi.org/10.1075/btl.43.17kel.

Kopczyński, A., Markiewicz, A. (1997), „Conference Text Types in Poland and the Teaching of Interpretation", [w:] Eberhard Fleichmann, Wladimir Kutz, Peter. A. Schmitt, red. Translationsdidaktik: Grundfragen der Übersetzungswissenschaft, Tübingen, Gunter Narr Verlag: 291-297.

Lane, H. (1996), Maska dobroczynności: deprecjacja społeczności głuchych, Warszawa, Wydawnictwa Szkolne i Pedagogiczne.

Lucas, C., Valli, C. (1992), „Language Contact in the American Deaf Community", [w:] Ceil Lucas, red. The Sociolinguistics of Sign Languages, Cambridge, Cambridge University Press: 11-40.

McKee, R., Napier, J. (2002), „Interpreting in International Sign Pidgin: an Analysis", Journal of Sign Language Linguistics 5(1), https://doi.org/10.1075/ sll.5.1.04mck.

Neumann-Solow, S. (1981), Sign Language Interpreting: a Basic Resource Book, Silver Spring, National Association of the Deaf.

Pöchhacker, F. (2004), Introducing Interpreting Studies, Abingdon, Oxon: Routledge.

Sacks, O. (1991), Seeing Voices, London, Picador, https://doi.org/10.4324/9780203 504802.

Stokoe, W.C. (1960), „Sign Language Structure: An Outline of the Visual Communication Systems of the American Deaf", Studies in Linguistics: Occasional Papers 8. Buffalo: Dept. of Anthropology and Linguistics, University of Buffalo.

Świderski, T.A. (2011), „Tłumacze języka migowego w historii” - referat wygłoszony na konferencji „Teoria i praktyka przekładu PJM. Tłumacze siłą Głuchych" organizowanej przez Stowarzyszenie Tłumaczy Polskiego Języka Migowego, Warszawa, 3-4 grudnia 2011.

Świdziński, M., Gałkowski, T. (red.) (2003), Studia nad kompetencja językowa i komunikacja niestyszacych, Warszawa: Uniwersytet Warszawski, Wydział Polonistyki, Wydział Psychologii, Polski Komitet Audiofonologii, Instytut Głuchoniemych im. ks. Jakuba Falkowskiego. 


\begin{abstract}
Abstrakt
Artykuł przedstawia wyniki badania przeprowadzonego na grupie 12 osób głuchych i 11 tłumaczy PJM, którego celem było zobrazowanie obecnego stanu rzeczy w thumaczeniu języka migowego w Polsce przy jednoczesnym spojrzeniu wstecz. Badani opisywali zmiany zaobserwowane w tym obszarze w ciągu ostatniego ćwierćwiecza. Wynika z nich, że sytuacja thumaczenia języka migowego w Polsce uległa znaczącej poprawie w kontekście językowym, tłumaczeniowym, prawno-administracyjnym i społecznym. Wiele aspektów tej sytuacji wymaga jednak dalszej poprawy, aby można było mówić o pełnej dostępności życia społecznego dla osób głuchych oraz o zawodzie tłumacza PJM jako w pełni sprofesjonalizowanym.
\end{abstract}

Słowa kluczowe: głusi, tłumacze PJM, język migowy, język foniczny, tłumaczenie języka migowego

\title{
Abstract \\ Sign Language Interpreting in the Opinions of Deaf Persons and Pol- ish Sign Language Interpreters
}

The article presents the results of a research conducted among 12 deaf people and 11 Polish sign language interpreters, aimed at depicting the state-of-the-art situation of sign language interpreting in Poland while it simultaneously reflects upon the past as well. The interviewees reported on the changes in this area over the last twenty-five years. According to them, situation in Poland has improved significantly with regard to language, interpreting as such, legal-administrative and social issues. Still, in many respects sign language interpreting needs further improvement in order to attain full accessibility for deaf persons as well as full professionalisation for sign language interpreters.

Keywords: the deaf, Polish sign language interpreters, sign language, spoken language, sign language interpreting 